\title{
Some new data concerning the Quaternary glaciation in the Romanian Carpathians
}

\author{
Petru Urdea', Anne U. Reuther ${ }^{2}$ \\ Received: November 2008 | Revised: April 2009 | Accepted: April 2009
}

\begin{abstract}
The aim of this paper is to present some new data from Pleistocene glacial deposits of some key areas in the Southern Carpathians, Romania. The results from detailed geomorphological mapping and surface exposure dating $\left({ }^{10} \mathrm{Be}\right)$ in the Retezat, Făgăraş and Parâng Mountains give insight into their Pleistocene glacial history. The Southern Carpathians are the highest mountain chain of the Romanian Carpathians, with 11 peaks higher than $2500 \mathrm{~m}$ a.s.l. Although evidence for Pleistocene glaciation in the Romanian Carpathians was pointed out over 125 years ago, the timing and extent of the glaciation is still controversially discussed. In the Retezat Mountains we focused our field work and boulder sampling on the north-facing Pietrele Valley, in the Parâng Mountains we worked in the north-facing Jieț valley. We present new results from geomorphological mapping from the eastern and central part of the Făgăraş Mountains, where landsliding and steep valley walls impede exposure dating. Two major glacial advances, $\mathrm{M}_{1}$, and $\mathrm{M}_{2}$ (in local terminology Lolaia and, respectively, Judele-Jieț) have been previously described. The most extensive M1-advance reached an elevation of 1,035 $\mathrm{m}$ a.s.l. in the Retezat Mts., some $250 \mathrm{~m}$ below the terminal moraines of the M2- advance. The timing of the M1 advance is uncertain but it occurred either during the Early Würm (MIS4) or during the Riss (MIS 6) glaciation, based on the relative chronology of pedological investigations. The exposure ages show that the younger M2 glacial advance (Judele-Jieț) was deposited during the late glacial at $16.8 \pm 1.8 \mathrm{kyr}$ in the Retezat Mountains and $17.9 \pm 1.6 \mathrm{kyr}$ in the Parâng Mountains. There is no evidence in the field for a glacial advance during the global Last Glacial Maximum (LGM); we therefore conclude that the glacial advance during the LGM was moisture-starved and therefore less extensive than the late glacial advance, which overran the LGM deposits. This is in good agreement with the sealevel data from the Mediterranean Sea, the moisture source for the region. The new investigations and geomorphological mapping in the eastern part of Făgăraş Mts. (Luțele-Berevoiescu area) allow establishing a stepwise evolution of glaciers in the last stages of the Pleistocene and allow differentiating between two ways of evolution of glaciers in their extinction stage, one in a normal ablation way, and the other one from glaciers to rock glaciers.
\end{abstract}

Key words: Quaternary glaciation, glacial landforms, Carpathians, Romania.

\section{Historical background}

The Carpathians are a distinct part of the Alpine-Himalayan orogenic chain, and are the backbone of Romania's relief, being situated in the central part of country (Fig. 1). Although the existence of Pleistocene glaciers in the Romanian Carpathians was pointed out over 125 years ago - in the Northern Carpathians (Tietze, 1878) and in the Transylvanian Alps (Lehmann, 1881, 1885) -, for the rest of the mountain areas with maximum altitudes below $2000 \mathrm{~m}$, the problem is still controversial. The situation is even stranger because, during the Pleistocene glaciers descended to 1050-1200 m a.s.l. in the highest mountains of Romania, such as in the Southern Carpathians (Făgăraş, Retezat, Parâng) - also called Transsylvanian Alps - and in Rodna Mountains in Eastern Carpathians.

The research of the Romanian glacial relief and of the effect of Pleistocene glaciation in this part of Europe has known four distinct periods.

1 Department of Geography, West University of Timişoara, Romania; e-mail: urdea@cbg.uvt.ro

2 Institute of Geography, University Regensburg, Germany, now at Department of Earth Science, Dalhousie University, Halifax, Canada, e-mail: anne.reuther@dal.ca 


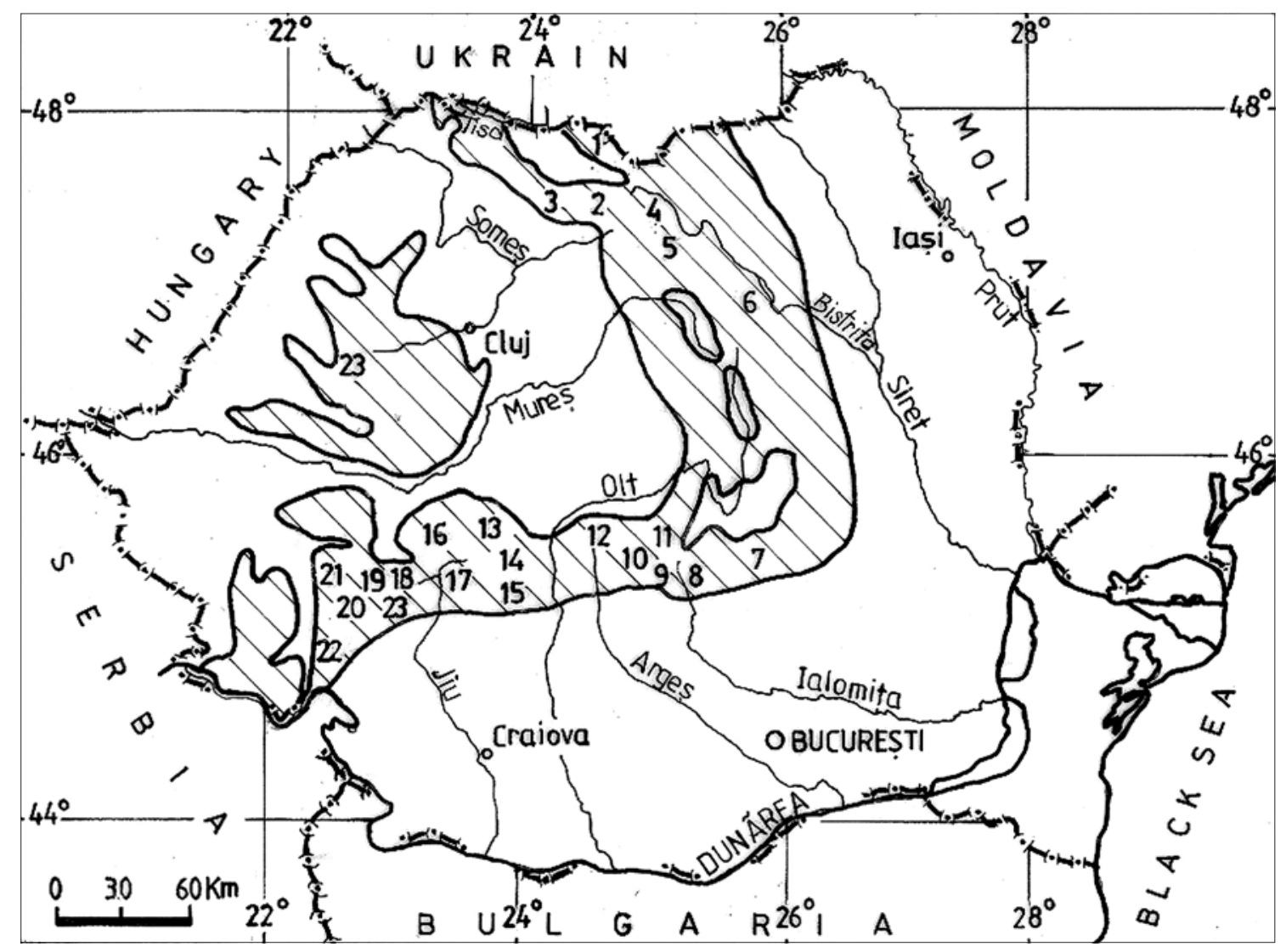

Figure 1 Position of the Carpathians Mountains in Romania and location of the mentioned area: 1- Maramureş Mts.; 2- Rodnei Mts.;3- Țibleş Mts.; 4- Călimani Mts.; 5- Suhard Mts.; 6- Ceahlău Mts.; 7- Siriu Mts.; 8- Bucegi Mts.; 9. Leaota Mts.; 10- Piatra Craiului Mts.; 11- lezer Mts.; 12- Făgăraş Mts.; 13-Cindrel Mts.; 14- Lotrului Mts.; 15.Căpățânei Mts.; 16- Şureanu Mts.; 17- Parâng Mts.; 18- Tulişa; 19- Retezat Mts. 20- Godeanu Mts.; 21- Țarcu Mts.; 22- Cernei Mts.; 23- Vâlcan Mts.; 24- Bihor Mts

The first period, that of pioneering, is characterised by the identification of the first glacial forms in the Carpathians of the Maramureş area by Tietze (1878) and in the Făgăraş Mountains by Lehmann (1881). Negating the relevance of the detailed descriptions, maps, photographs and croquises, these glacial marks identified by Lehmann have been contested by Inkey $(1884,1892)$ and Primics (1884). These consider that all forms - lacustrian overdeepening depressions, cirques and valleys - the results of water erosion, the glacial steps results from the normal progression of fluvial erosion, while morainic deposits are in reality scree deposits.

After these, we mention the minute analysis of some typical glaciated areas in the Southern Carpathians (de Martonne, 1900) and in the Eastern Carpathians (Sawicki, 1911), where a special attention was devoted to Rodnei Mountains. Glacial marks have also been noticed in Țarcu and Godeanu Mountains (Schafarzik, 1899, 1901), on the southern slope of the Parâng Mountains (Mrazec, 1898; de Martonne, 1899), in Bucegi Mountains (Popovici-Hațeg, 1899). There were suppositions, in this period, that some glacial forms were present also in Călimani Mountains and Țibleş Mountains (Sawicki, 1911). Although early, conditions were favorable for the production of the first papers dedicated on the glaciation of the Southern Carpathians (Martonne, 1899, 1900, 1901, 1904; Puchleitner, 1902; Lehmann, 1905) or of the entire Carpathian ridge (Sawicki, 1912). A true geomorphological monograph of the Transylvanian Alps is due to Martonne (1907), with a special attention to the glacial landforms and Quaternary.

The second period, between the two World Wars, is distinguished by the discovery of other glaciated areas, like those in Bucegi Mountains, (Wachner, 1929, 1930), Siriu Mountains (Orghidan, 1932), Călimani Mountains (Someşan, 1933) and Țibleş Mountains (Kubijovici, 1934), and also by the publication of some synthesis works, dedicated either to the entire Carpathian chain (Pawlowski, 1934) or only to the Eastern and Southern Carpathians (Kräutner, 1930). Although largely grounded in the data of the works of de Martonne (1907), Kräutner makes a presentation of the glacial morphology of each mountain area representing on attached maps the maximum extension of the Quaternary glaciers.

The third period, i.e. the postwar period, is characterised by an increase of interest in the research of glacial relief and the deciphering of the evolution of glacial periods in the Romanian Carpathians. This must be associated, for the period between 1950 and 1970, to studies on areas like Bucegi Mountains (Michalevic-Velcea, 1961), Godeanu Mountains (Niculescu, 1965) and Rodnei Mountains (Sîrcu, 1978) and with the research activities connected to the editing of the synthesis papers (Niculescu et al., 1983). Thus, we mention the works of Niculescu $(1958,1961,1971)$, Nedelcu (1962), or Sîrcu $(1963,1964)$. Closer to our days, research dedicated to glacial relief and Pleistocene glaciation have been carried out on Retezat Mountains (Urdea, 1989, 2000) or Făgăraş 
Mountains (Florea, 1998). Also, even if the glacial landforms are questionable, the problem of the Quaternary glaciation was pointed by Constantinescu $(1984,1992)$ for the Piatra Craiului Mountains. In the latter period the Pleistocene glaciation in the Romanian Carpathians was considered by some authors as "Carpathian glaciation" (Velcea, 1973).

Most studies consider the existence of two major glacial phases, corresponding to the alpine Riss and Würm phases (Niculescu et al., 1960, 1983; Posea et al., 1974). For Rodnei Mountains, situated in the north of the Eastern Carpathians, some suggested the existence of a third glacial phase, Mindel, Riss and Würm (Sîrcu, 1964, 1978). However, there are authors who state the existence of just one glacial phase, Würm, with 2-3 stages (Posea, 1981).

The detailed mapping of Retezat Mountains' relief has led to the identification of many series of moraines, situated at altitudes between $1035-1050$ and $2150 \mathrm{~m}$ a.s.l., and ion consequence, this supported the idea that at least ten glacial advances took place in this mountain range during Riss and Würm (Urdea, 1989, 1993, 2000). Later on, similar situations have been described in other mountain areas out of the Southern Carpathians. These papers also point out that the last glacial remains, affecting just some glacial cirques situated above $2150 \mathrm{~m}$ a.s.l., can be referred to the Preboreal, (Urdea, 2004). Recently, the first radiometric age from glacial relief on the Romanian Carpathians, in Pietrele Valley (Retezat Mts.), prove for the morainic deposits situated between 1350 and $1902 \mathrm{~m}$ a.s.l. ages situated between $16.8 \pm 1.8 \mathrm{kyr}$ and $11.4 \pm 1.3 \mathrm{kyr}$ (Reuther, 2005; Reuther, et al., 2007).

Nevertheless, even today, in spite of the recognition of widespread glacial features, some authors deny their widespread occurrence (e.g. Pop, 2000; Velcea, 2001; Posea, 2002, 2003; Ielenicz, Pătru, 2005), and the ideas promoted during $6^{\text {th }}$ and $8^{\text {th }}$ decades of the $\mathrm{XX}^{\text {th }}$ century still persist.

\section{Study area}

The Romanian Carpathians represents the south-eastern side of the Carpathians, being situated between $44^{\circ} 29^{\prime}$ and $48^{\circ} 6^{\prime} \mathrm{N}$ latitude and between $21^{\circ} 28^{\prime}$ and $26^{\circ} 58^{\prime} \mathrm{E}$ longitude. Their length is over $910 \mathrm{~km}$ - almost $54 \%$ of the entire length of the Carpathians - , and they cover an area of $66303 \mathrm{~km}^{2}$.

The Carpathians are included in the northern branch of the European system of the Alpides and are the results of Mesozoic and Cenozoic continental collision, materialize in the presence of several nappes complexes and thrust sheets. Especially in the Apuseni Mts., Southern Carpathians and in the central axial area of the Eastern Carpathians, the metamorphic rocks with numerous granitoid plutons are characteristic, sedimentary rocks being present in the marginal zones. In the south-east part of Apuseni Mts. and on the eastern side of the Eastern Carpathians the Flysch Zone represents a prominent tectonic unit. Also, in the southern part of Apuseni Mts. and on the western side of the Eastern Carpathians, to the Transylvania Basin, MioPliocene volcanic rocks and deposits are present ("volcanic chain"). A complex inner faults system is connected by the appearance of the evolution of the representative tectonic basins.

Although, the mean elevation of these mountains is 840 $\mathrm{m}$, only $34 \%$ of the chain have altitudes higher than 1500 $\mathrm{m}$. However, there are 11 peaks higher than $2500 \mathrm{~m}$ a.s.l., the highest peak being Moldoveanu, with $2544 \mathrm{~m}$ in the Făgăraş Mountains.

In the high area of the Romanian Carpathians the geomorphological landscape exhibit glacial sculpture, with cirques, steep slopes and U-shaped valleys, associated either with sharp peaks and ridges - a typical alpine landscape for central part of the Făgăraş, Retezat, Parâng and Rodnei Mountains - , with rounded mountain tops and interfluves, integrated on the some levelled surfaces, true peneplaines. As early as of the beginning of $\mathrm{XX}^{\text {th }}$ century, Martonne (1907) identified and described in the Southern Carpathians three peneplaines, Borăscu at 1800-2200 m a.s.l., Râu Şes at 1400-1600 m a.s.l. and Gornovița at 1000$1200 \mathrm{~m}$ a.s.l. Especially in the sedimentary area the structural and karstic landforms are characteristic.

The aim of our paper is to present some new data concerning the Pleistocene glaciation in the Romanian Carpathians. After field investigations that led to the geomorphological mapping of glacial landforms - e.g. glacial cirques and valleys, roches moutonnées, striations, erratic blocks, moraine deposits - we present a new image of the Pleistocene glaciers in some Carpathian areas.

\section{Methodology}

For the reconstruction of the Quaternary glaciation reconstruction in the our interest area the main method, during several years was the field surveys and detailed geomorphological mapping in some key areas. Based on an international research program, the new method of cosmogenic radionuclides was applied for absolute ages. The methodology was those presented in the previous papers (Reuther, et al., 2007). Apparent exposure ages were calculated from the measured nuclide concentration, based on the ratios of the radionuclide to the stable nuclide, measured using accelerator mass spectrometry (AMS) at the PSI/ETH Zurich tandem accelerator facility.

\section{Field data and discussion}

In the Retezat Mountains we focused our field work and boulder sampling on the north-facing Pietrele Valley and in the Parâng Mountains we worked in the north-facing Jieț valley. Two major glacial advances, $\mathrm{M}_{1}$, and $\mathrm{M}_{2}$ (in local terminology Lolaia and, respectively, Judele-Jieț) have been previously described (Reuther, et al., 2007). The most extensive M1-advance reached an elevation of $1035 \mathrm{~m}$ a.s.l. in the Retezat Mts., some $250 \mathrm{~m}$ below the terminal moraines of the $\mathrm{M}_{2}$ - advance. The timing of the $\mathrm{M}_{1}$ advance is uncertain but it occurred either during the Early Würm (MIS4) or during the Riss (MIS 6) glaciation, based on the relative chronology of pedological investigations (Reuther, et al., 2004). The exposure ages show that the younger M2 
glacial advance (Judele-Jieț) was deposited during the late glacial at $16.8 \pm 1.8 \mathrm{kyr}$ in the Retezat Mountains and $17.9 \pm 1.6$ kyr in the Parâng Mountains.

The moraines of the M1-advance were devoid of moraine boulders suitable for exposure dating. To constrain the time of the M2-glacial advance, 15 boulder - many of them erratics -and two bedrock surface located on moraine remnants along the valley and one bedrock sample from an ice transfluence location were exposure dated. The exposure ages show that the initial M2-glacial advance occurred just before $16.8 \pm 1.8 \mathrm{kyr}$ depositing a small outer moraine. The glacier melted back only 10-15 $\mathrm{m}$ and deposited a moraine that was exposure dated to $16.1 \pm 1.6 \mathrm{kyr}$. Deglaciation from this moraine happened no later than $16.0 \pm 1.7 \mathrm{kyr}$. Some moraine surfaces of the M2advance did not stabilize until about $13.8 \pm 1.5 \mathrm{kyr}$ indicating prevalent periglacial climatic conditions (Reuther, et al. 2007). This is also supported by pollen records from others which indicate a spread of vegetation in the Retezat Mountains at this time.

Two exposure ages constrain the time of a glacial advance during the Younger Dryas period. The glacial advance that deposited the moraine in between two massive boulders (horizontal distance $350 \mathrm{~m}$ ) falls in the time period between deposition of the older $(13.6 \pm 1.5 \mathrm{ky})$ and the younger (11.4 $\pm 1.3 \mathrm{kyr})$ of the two boulders.

In the Parâng Mountains, with an expressive glacial landscape, in the north-facing Jieț valley the situation is close to Retezat Mountains, the five exposure ages being between $16.7 \pm 1.5$ and $17.9 \pm 1.6 \mathrm{kyr}$.
In the eastern part of Făgăraş Mountains, - the highest altitude is $2321 \mathrm{~m}$ in Ludişoru II Peak, while in the central segment the highest altitudes are above $2500 \mathrm{~m}$. In this area, the front of the glaciers are found even below $1200 \mathrm{~m}$ a.s.l A good example is the Dejani Valley where, a typical glacial valley trough recognised at ca 1100 suggests that during the maximum Pleistocene advance the glacier expanded even below. Moraine deposits and erratic blocks are present on the valley floor. Frontal moraines, possibly deposited during the Last Glacial Maximum, can be found at 1200-1240 $\mathrm{m}$ and at 1390-1410 $\mathrm{m}$ (Fig.2A). Higher up in the valley there are also stadial moraines, tentatively attributed to the end of Late Glacial, situated above $1850 \mathrm{~m}$ altitude. In the up per part of the valley cirque, there are 4 stadial moraines situated between 1860 and $2010 \mathrm{~m}$ that represents the latest part of the Last Glaciation. In the cirque at the western side of the valley (Dejani West), we also recognised a rock glacier. This is a secondary rock glacier (sensu Corte, 1976) derived from an ice-cored moraines (sensu Østrem, 1964). Behind this rock glacier there are three stadial moraines (Fig. $2 \mathrm{~B}$; Photo 1). The entire morphologic ensemble is situated between 2020-2130 $\mathrm{m}$ a.s.l.. Also, here in the eastern part of Făgăraş Mountain, the glacial morphological features of Belia Mare (Photo 2) and Buzduganu cirques are just as significant.

The lack of radiometric ages prevent a clear setting of these glacial advances. We tentatively associate these events with the cooling episodes characterised by an increase in the number of Pinus and Artemisa during the LPAZ 6, $\mathrm{LPAZ}_{7}$ and LPAZ 8 phases of the Younger Dryas-Prebore-

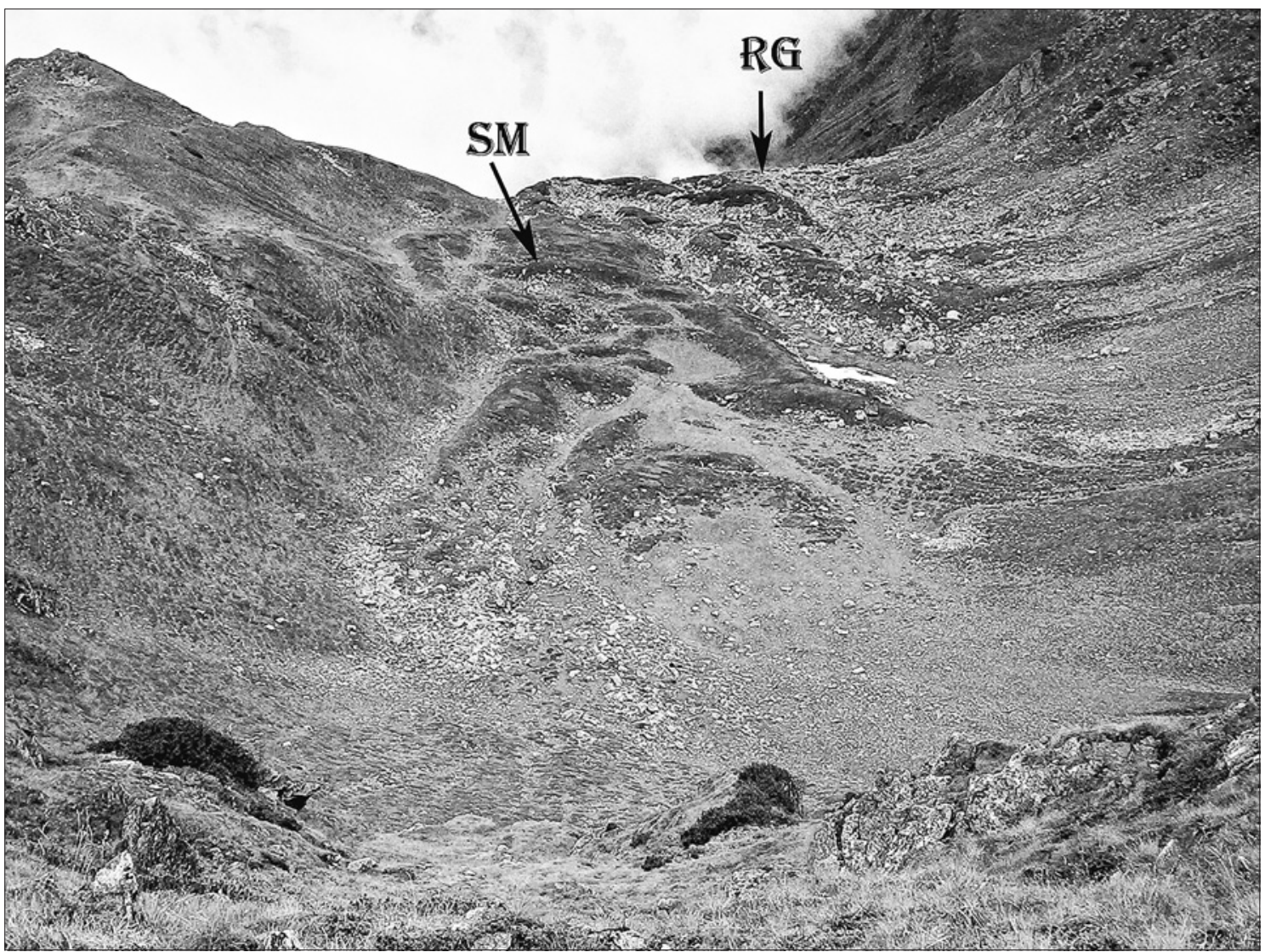

Photo 1 Geomorphological aspects of Dejani Vest cirque (Făgăraş Mts.); RG - rockglaciers, SM - stadial moraine (Younger Dryas) 


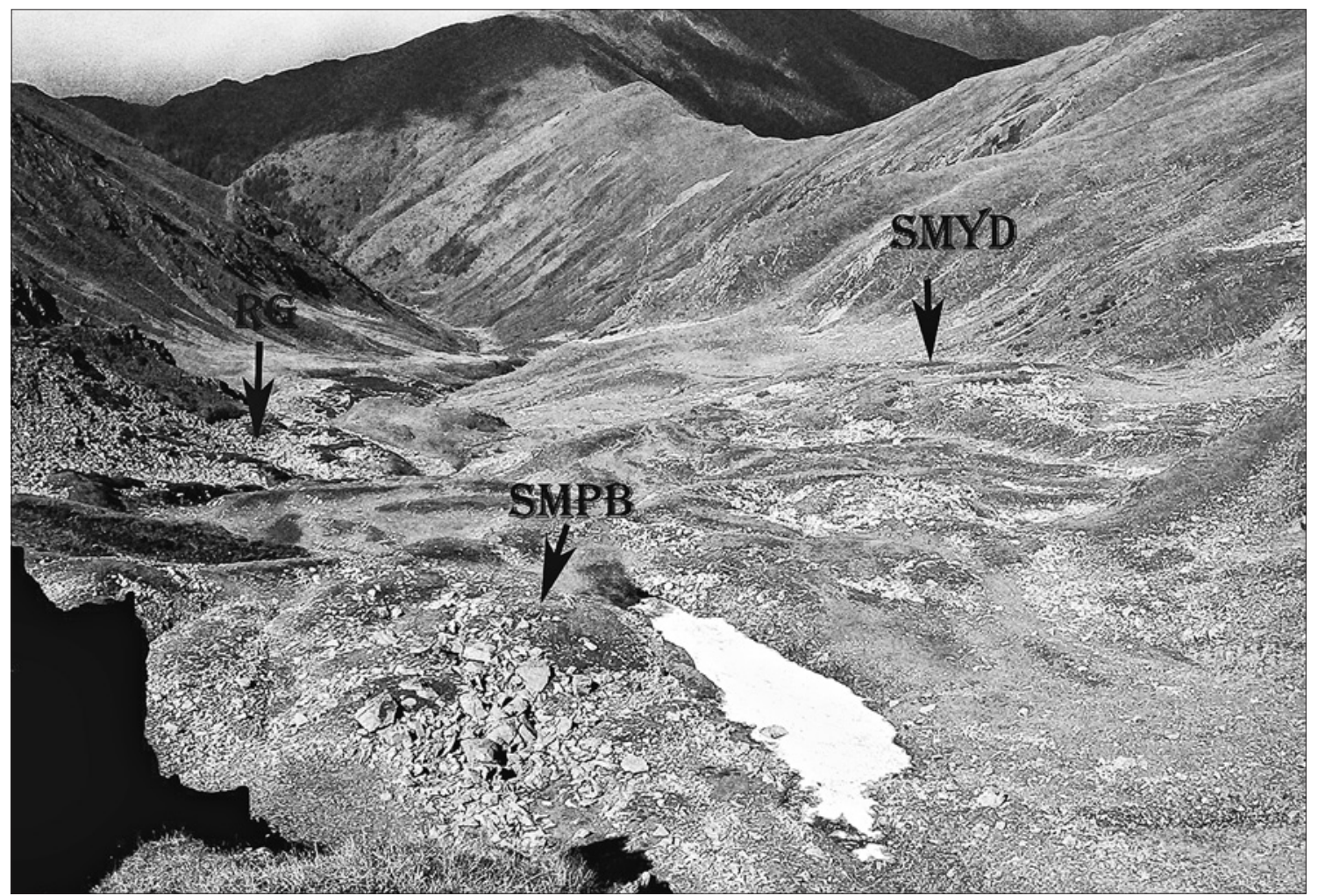

Photo 2 Geomorphological aspects of Belia Mare cirque (Făgăraş Mts.); RG - rockglaciers (Younger Dryas), SMYD - stadial moraine (Younger Dryas), SMPB - stadial moraines (Preboreal)

al interval, noticed in borehole drilled in the marsh at Avrig (60o m a.s.l.) in the Făgăraş Depression (Tantău et al., 2005).

Other glacial evidences are found, on the northern slope, of the Valea Doamnei (valley), as well as on eastern side of the Fundu Caprei cirque, on the southern slope in the central part of the Făgăraş Mountains. Here, Arpaşu Mic hanging cirque is occupied by a rock glacier which is in $\mathrm{di}-$ rect contact with a small moraine amphitheater (Fig. $3 \mathrm{~A}$ ). This situation suggests the existence of some spatial connections between the glacier originating in this cirque and the glacier from the main part of the cirque and whose evolution is decipherable by means of the two stadial moraines
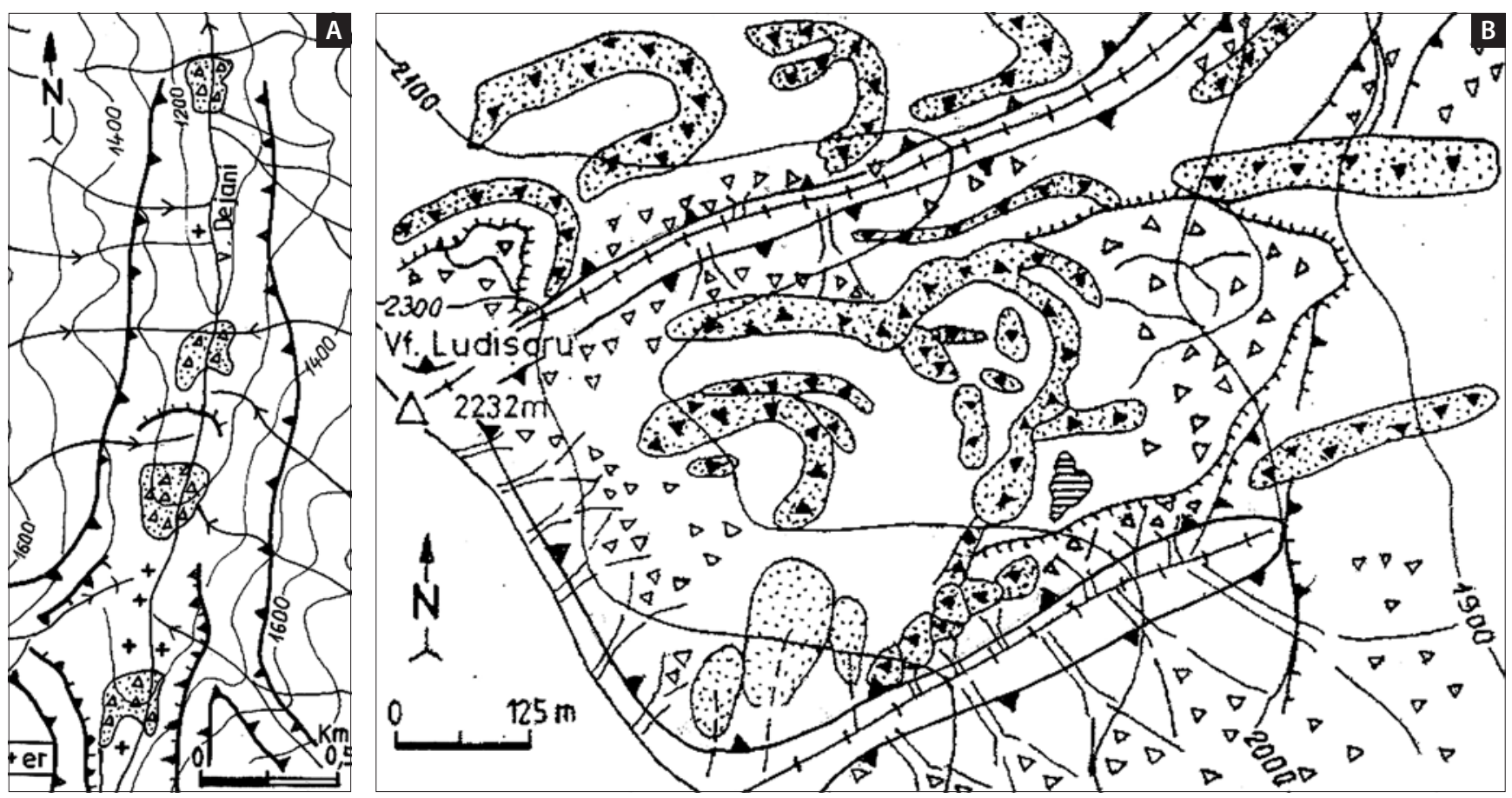

Figure 2 Geomorphological sketch map of Dejani glacial valley (A) (er. - erratic) and Dejani West cirque (B) (Făgăraş Mts): 1- peaks and ridges; 2- rounded crests; 3- glacial cirque; 4- glacial transfluence pass; 5- glacial scarp; 6- secondary glacial trough; 7 - roches moutonnées; 8- moraines; 9- rockglaciers; 10- protalus rampart; 11- avalanche paths and talus cones; 12- scree slopes; 13- debris flows tongues; 14- rivers and lakes 


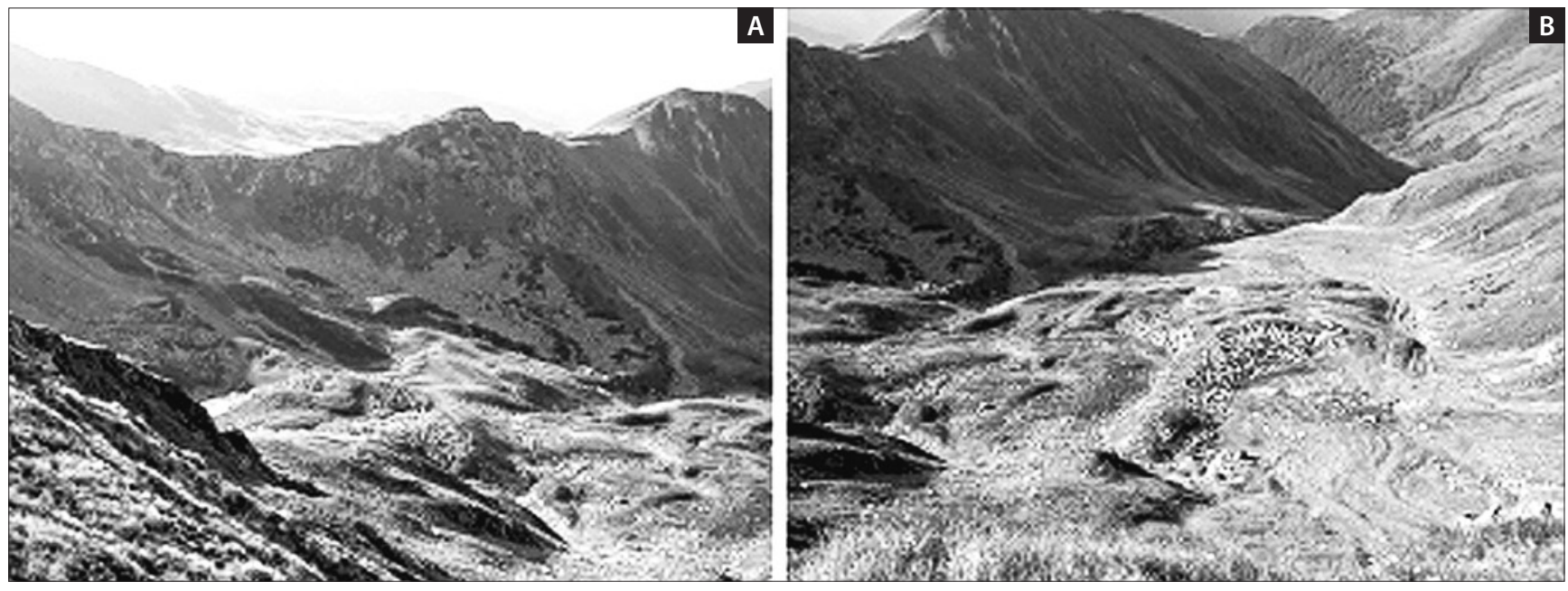

Figure 3 Geomorphological sketch map of Arpaşu Mic area (A) and Grohotişu cirque (B) (Făgăraş Mts): 1- peaks and ridges; 2rounded crests; 3- glacial cirque; 4- glacial transfluent sadle; 5- glacial scarp; 6- secondary glacial trough; 7 - roches moutonnées; 8- moraines; 9- rockglaciers; 10- protalus rampart; 11- avalanche paths and talus cones; 12- scree slopes; 13- debris flows tongues; 14rivers and lakes

situated in its axial side. The situation mentioned above underline the fact that several distinct stages exists in the evolution of the Pleistocene glaciers in the area of the Romanian Carpathians previously considered to have been affected by just one glacial stage (Posea, 1981). On the other hand the cirque morphology suggest the morphogenetic and spatial relations between rock glaciers and typical glacial landforms, the moraines. For example, in the northern part of the cirque is a direct spatial and lithostratigraphic connection between latero-frontal moraine and marginal wall of the rock glaciers.

In the south facing, Grohotişu cirque, situated on the western part of the Făgăraş Mountains, two generations of rock glaciers are recognisable, covering a wide stadial moraine (Fig. $3 \mathrm{~B}$ ). The fact that the two generations of rock glaciers expand until approx. $1930 \mathrm{~m}$ proves that, during its last evolutionary stages, the glacier was covered by huge masses of debris originating in the surrounding walls, evolving afterwards into secondary rock glaciers. As I had previously mentioned (Urdea, 2004), the evolutionary succession was the following: ablation complexes $\rightarrow$ ice-cored rock glaciers $\rightarrow$ debris rock glaciers or secondary rock glaciers, valid certainly for the geomorphology of Arpaşu Mic and Grohotişu cirques. Therefore, the three distinct morphological situations from the Dejani West, Arpaşu Mic and Grohotişu cirques, show distinct evolutionary responses of the glaciers during their growth. For a good understanding of evolutionary succession, the distinct morphochronological sequences of the rock-glaciers must be correlated with the variability of the morphogenetic factors (lithology, local topography of cirques floor, proximity of the rock walls, microclimatic conditions etc.).

Another example is that of Şureanu Mountains. Glacial landforms were recognised in the past (Lehmann, 1885) although later researches (Niculescu, 1969) didn't bring out any novelties. Exhaustive geomorphologic mapping of the relief led to a new comprehension of the Quaternary glacial development in this mountain area (Urdea, Drăguț, 2002 2003). The moraines identified confirm the existence of no less than five phases (stages) in the evolution of the glaciers, the largest one, the Cârpa glacier, coming down valley until 1530-1550 m a.s.l., reaching an area of only $1.325 \mathrm{~km}^{2}$ (Fig. 4).

The reconstructions made on the basis of the mapped glacial morphology, allow us to establish that during the major glacial advance glaciers totalled approx. $6.5 \mathrm{~km}^{2}$, i.e. only $0.41 \%$ of this mountain area. This modest surface of the glaciated area is explained by the somewhat internal, more continental, position in the Carpathian chain, but mainly by the wide extension of the summit peneplaines, connected with the low densities of larges basins, with a favourable orientation. These geomorphological characteristics of the landscapes prevented the accumulation of large amounts of snow that would eventually turn into ice. A similar situation is in fact present in Cindrel, Lotrului, Căpățânei and Leaota Mountains, which are also similar from the point of view of altitude - $2130 \mathrm{~m}$ Pătru Peak (Şureanu Mts.), 2244 m - Cindrelu Peak (Cindrel Mts.), 2242 m. Ştefleşti Peak (Lotrului Mts.), 2124 m - Ursu Peak (Căpățânei Mts.), 2133 m Leaota Peak (Leaota Mts.). In contrast with the above mentioned situation are Țarcu Mountains, situated on the western side - more humid than central and eastern part of the Southern Carpathians, where peneplaines are also present. Having the highest altitude 2190m in Pietrii Peak, the highest area of the Tarcu Mountains had been powerfully affected by glaciation, the total surface of the glaciers reaching approximately $55 \mathrm{~km}^{2}$ (Table 1 ).

A special attention was oriented to the mountain areas with a controversial situation about the existence of Pleis tocene glaciation. However, during recent field researches several glacial niches and cirques, erratic blocks and mo raine deposits have been recognised in T,ibles and Suhard Mountains, in the Eastern Carpathians, in Leaota, Tulişa, Cernei, Muntele Mic and Oslea Mountain in the Southern Carpathians, and in Bihor Mountains in the Apuseni Mountains. Detailed geomorphological mapping allow us to reconstruct the Pleistocene glaciers in this mountains areas.

Cernei Mountains, situated in the South-Western part of the Southern Carpathians and with general orientation SW-NE, although reach 1928 in Dobrei Peak, are usually 


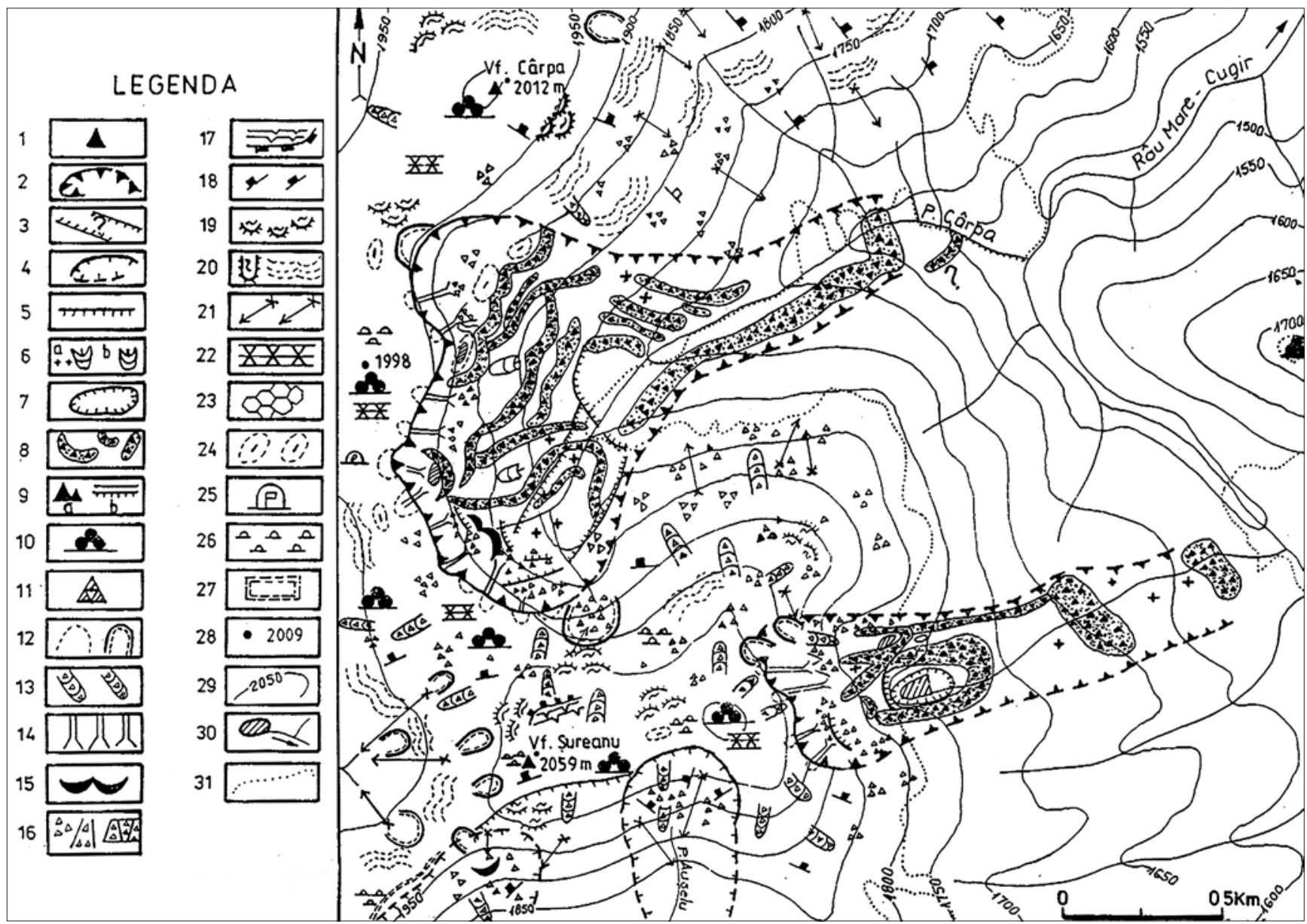

Figure 4 Geomorphological map of Şureanu-Cârpa area (Şureanu Mountains): 1. peak; 2.glacial cirque and valley; 3. possible glacial valley; 4. glacionival cirque; 5. glacial rock bar; 6. erratics (a) and roche moutonnées; 7. overdeepening depression; 8. moraines; 9. rocks (a) and cryergic-lithological scarps (b); 10. tor; 11. periglacial tamp; 12. nival semifunnel (a) and niche (b); 13.rock rivers; 14. avalanche paths; 15. protalus ramparts; 16 talus cones and scree slopes; 17. cryoplanation terraces; 18 . ploughing blocks; 19. solifluxion terracettes; 20. solifluxion ondulations; 21 . nivo-fluvial gullys; 22 . periglacial pavemets; 23 . patterned grounds; 24 . nival microdepressions; 25. fossil palsen; 26. periglacial hummocks; 27. Roman camp; 28. elevation; 29. contour lines; 30 . rivers and lakes; 31. upper timberline (after Urdea, Drăguț, 2002-2003)

considered an area that was not affected by Pleistocene glaciation. However, during recent field researches several glacial niches have been recognised along the NW side of the ridge, situated between Baldoveni Peak (1800 m) and Babii Peak $(1825 \mathrm{~m})$, the glaciated surface amounting to only 0.3 $\mathrm{km}^{2}$ (Fig. 5).

If we take into consideration the fact that in the previously described Țarcu, and also Godeanu Mountains, situated in the neighbourhood and not much higher in altitude, Pleistocene glaciation had been much more extensive, we must ask the reason of such a major discrepancy. In our opinion, this inconsistency is the result of both the preglacial landforms with much steeper slopes - slopes that prevent large accumulations of snow (Evans, 1977, 2005), and, certainly, of the general SW-NE orientation of the main ridge

An interesting situation is that of Muntele Mic Mountain, situated in the NW part of Țarcu Mountains reaching a maximum elevation of $1802 \mathrm{~m}$. The morphology is dome-shaped as a result of the deformations that affected the Borăscu peneplaine. Given the low altitude of this mountain area, the existence of some glacial landforms was never considered (e.g. Niculescu \& Nedelcu, 1961) although glacio-nival cirques have been identified and mapped but never accounted for (Nedelcu \& Niculescu, 1961).

Detailed researches led to the finding of erratic blocks and moraine deposits till 1410-1440 m. In some places the upper part of the cirques walls are in contact, by gentle slopes, with nivation niches. All this morphological elements enabled the reconstruction of the Pleistocene glaciers and firn fields, oriented mainly towards N, NE, and ESE (Fig. 6) as a consequence of the influence on the genetic factors of glacier ice given by the general configuration of the relief.

In the Tibleş Mountains, in the Eastern Carpathians, the presence of glacial landforms is still subject to discussion. A part of the Northern Group of the Eastern Carpathians (Fig. 1), is orientated West-East, - reaches $1842 \mathrm{~m}$ at Tibles Peak-. Many researches disregard the existence of glacial landforms, (e.g. Coteț, 1973; Posea et al., 1974), while others state, very briefly, the existence of Pleistocene glaciers in the area. Some of these statements are like "on the northern slope of the Tibles we may find picturesque glacial landforms" (Kubijovici, 1934), "Țibleş had some glaciers, which are noticeable especially on the Maramuress slope, in the wide valleys with glacial aspect situated under the peak" 


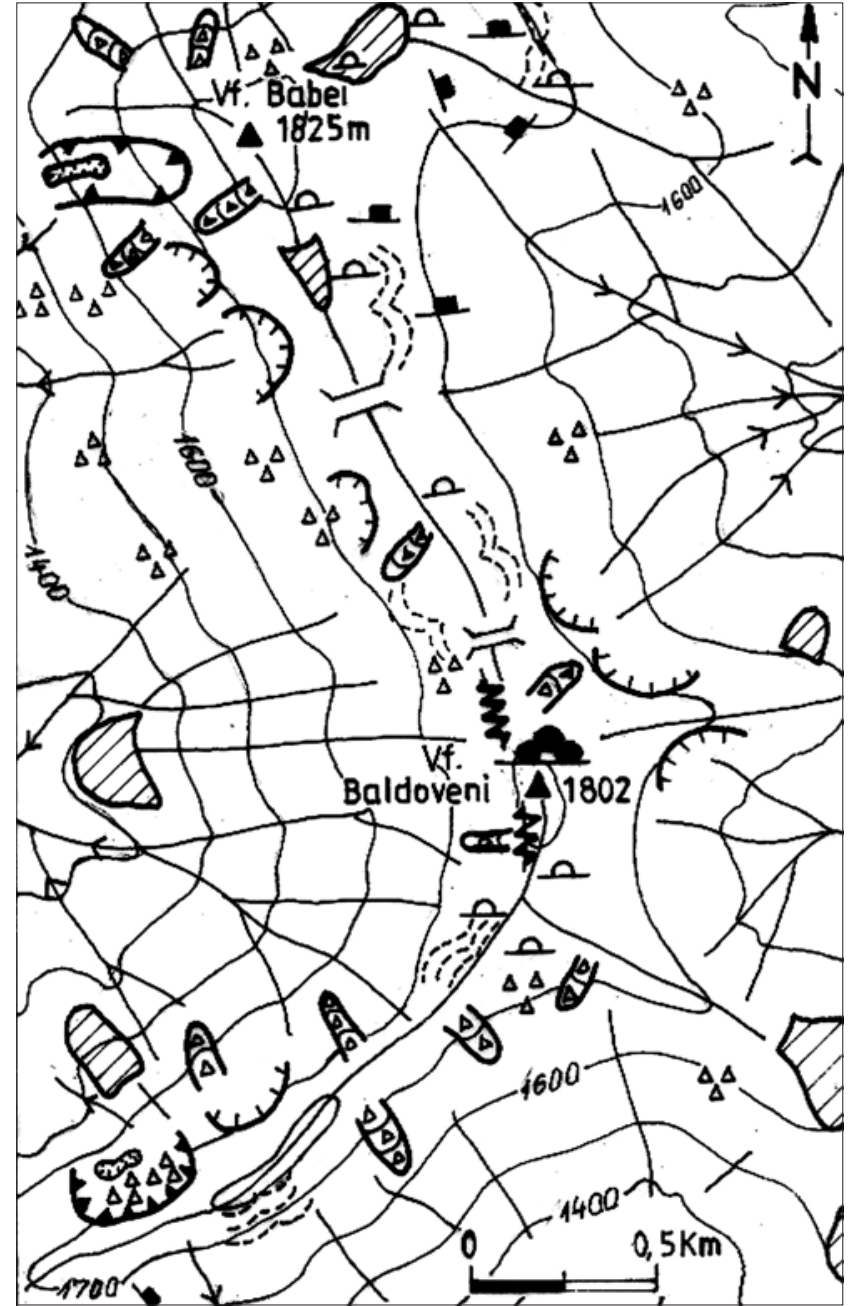

Figure $\mathbf{5}$ Geomorphological sketch map of the central part of the Cernei Mts. (Legend like in fig. 4)

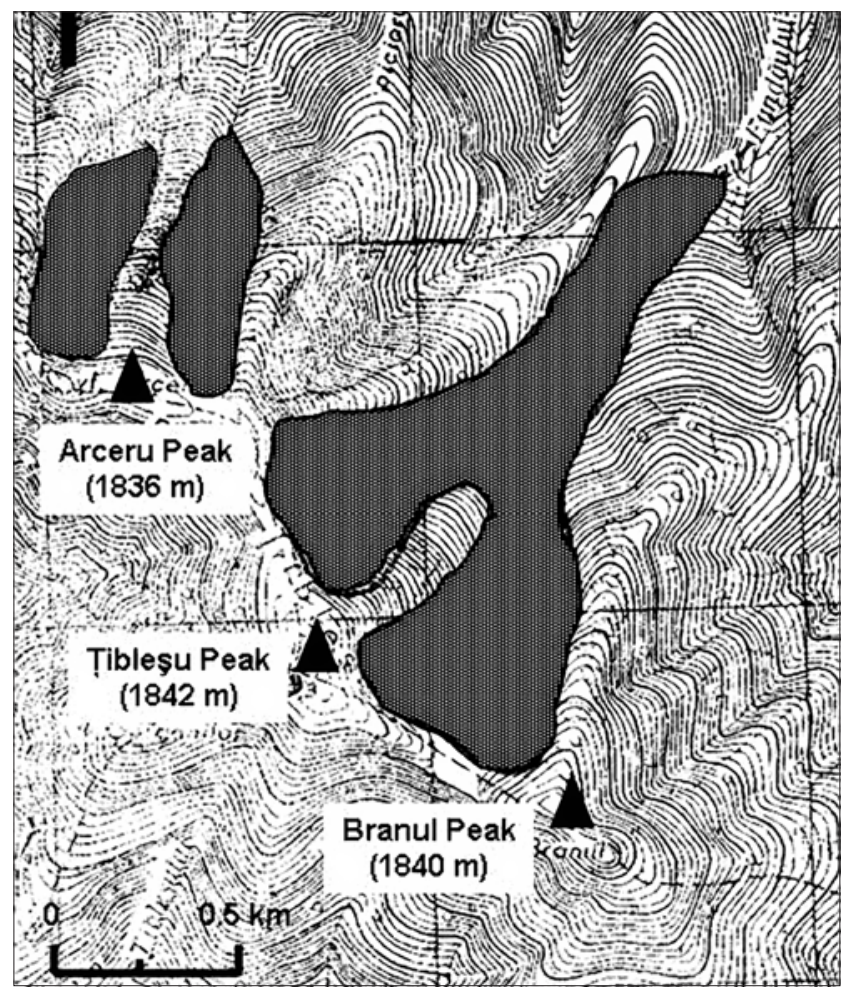

Figure 7 The reconstructed Pleistocene glaciers in the Țibleş Mountains

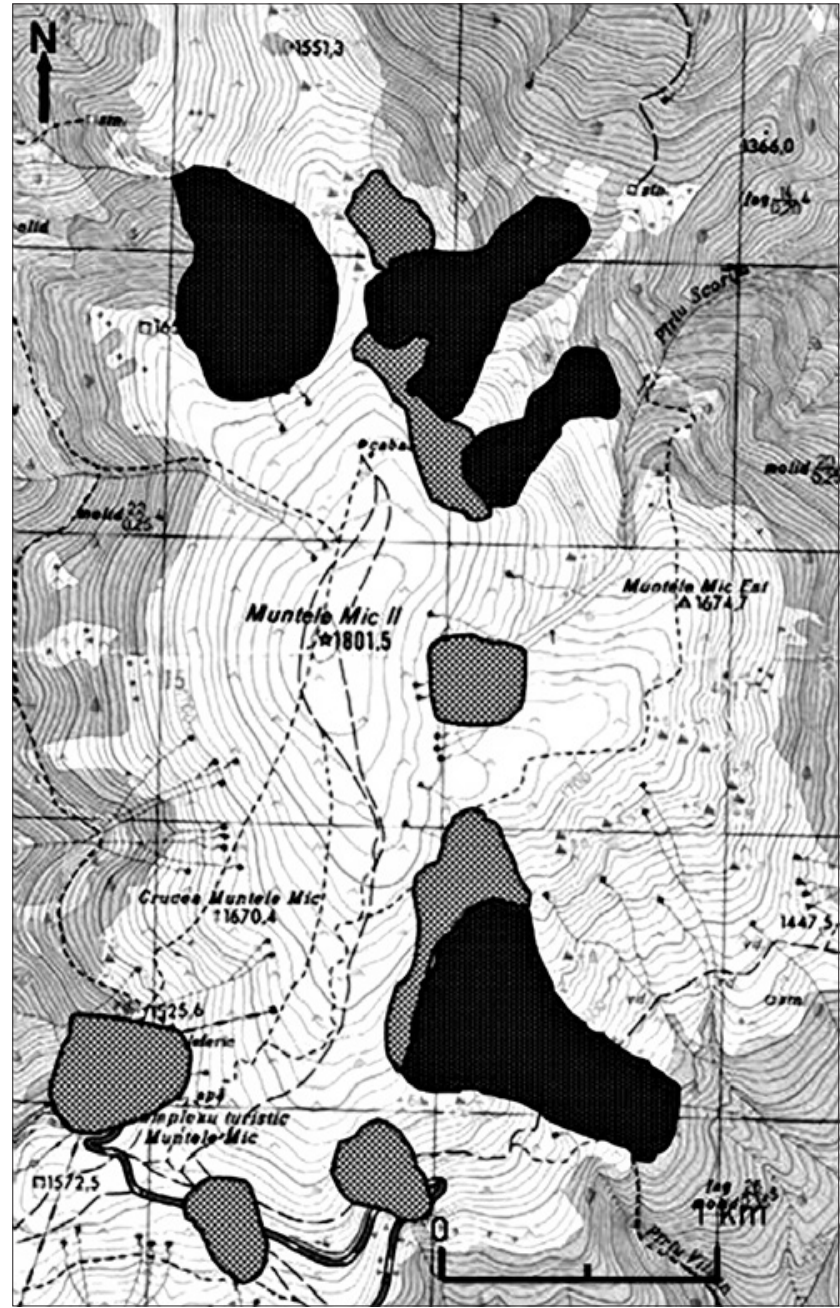

Figure $\mathbf{6}$ The reconstructed Pleistocene glaciers and firn field in the Muntele Mic Mountain

(Moraru, 1942), while others consider them to be nothing more than nival landforms (Posea, 1962). Late researches confirm the existence of two glacial cirques under the ridge between Țibleș Peak and Arcer Peak, which are orientated towards NNE (pers. comm. M. Mândrescu, 2005) and also of two glacial niches located north of Arcer $(1830 \mathrm{~m})$ and with northern orientation. According to our glaciological reconstruction, the glacier formed during the Last Glacial Maximum (LGM) descended the Izvoru Fundăului Valley to approx. $1400 \mathrm{~m}$ altitude, reaching a total length of rough $1.5 \mathrm{~km}$, the total surface of the glaciated area being estimat ed ca. $1 \mathrm{~km}^{2}$ (Fig. 7).

Still in the Northern Group of the Eastern Carpathians, latest researches (pers. comm. M. Mândrescu, 2005) identi fied two glacial niches in Suhard Mountains, north of Omu Peak (1932 m), at the spring of Rusca brook. The reconstructed surface of this glaciers is only $0.587 \mathrm{~km}^{2}$.

Apuseni Mountains are the lowest mountain unit of the Romanian Carpathians, with only 3 peaks higher than 1800 $\mathrm{m}$ and the issue of Pleistocene glaciation was not considered, except for Bihor Mountains, the highest mountains, with an altitude of $1849 \mathrm{~m}$ at Curcubăta Mare Peak or Bi hor Peak. The presence of glacial landforms was first debated by Szadeczky (1906), although the frontal moraines described near Stâna de Vale, are in reality a mixture of scree deposits and alluvial fan deposits (Martonne (1922). Saw- 


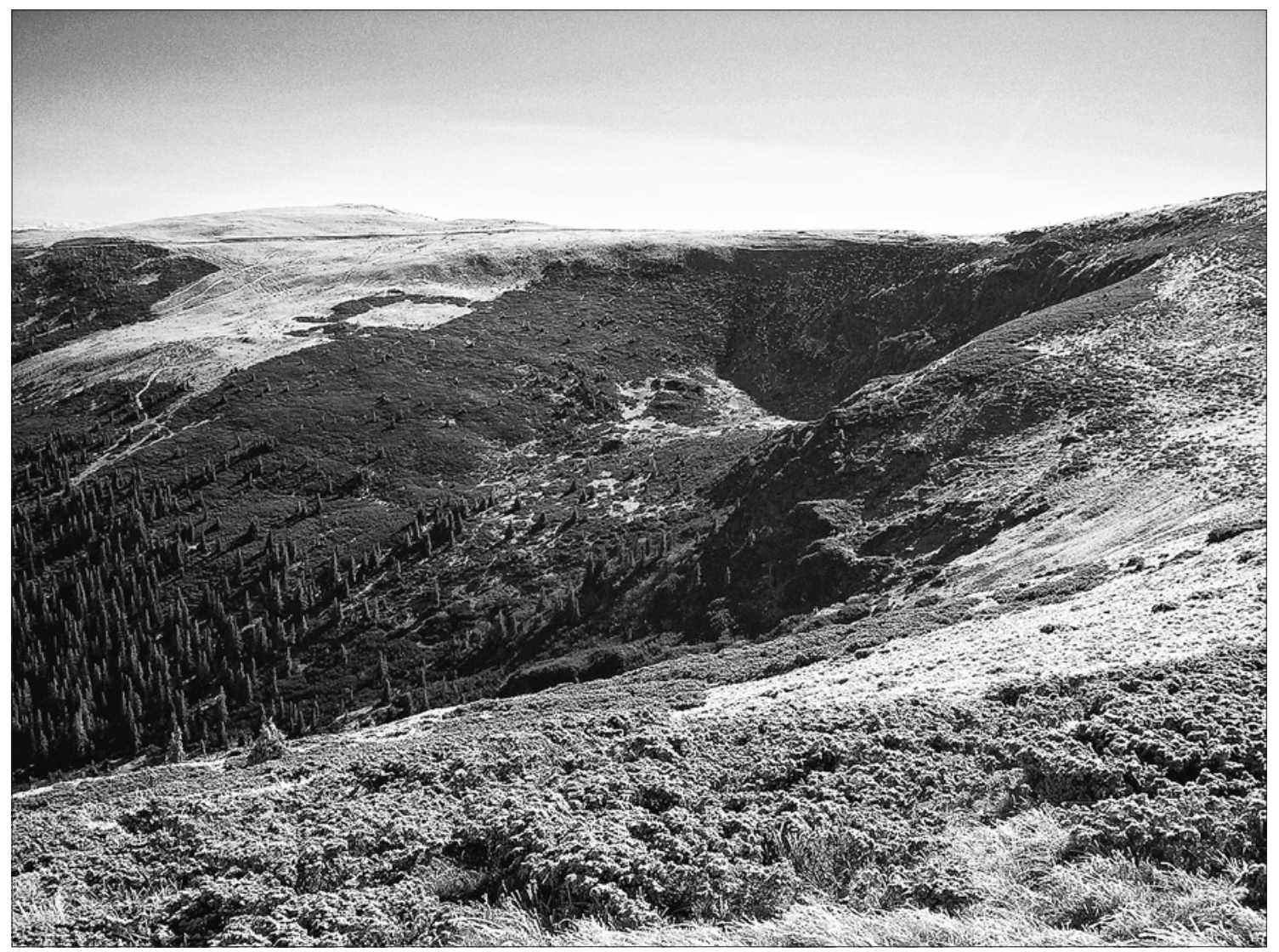

Photo 3 General aspects of Curcubăta Mare cirque (Bihor Mts.)

icki (1909) described a glacial cirque at the NE of Curcubăta Mare Peak (Photo 3), although Martonne (1922), and later Berindei (1971), based on a more detailed investigation considered such landforms to be of cryo-nival origin. However, Mac et al. (1990) stated that there is a glacial cirque under Curcubăta Mare together with a 1-1.5 km long glacial valley.

Our investigations confirmed the latter interpretation and enabled the precise configuration of the total extension of the Pleistocene glaciation in this mountain area (Fig. 8). During the Last Glacial Maximum the total surface of the glaciers was $1.88 \mathrm{~km}^{2}$. The glacial cirque of Bihor

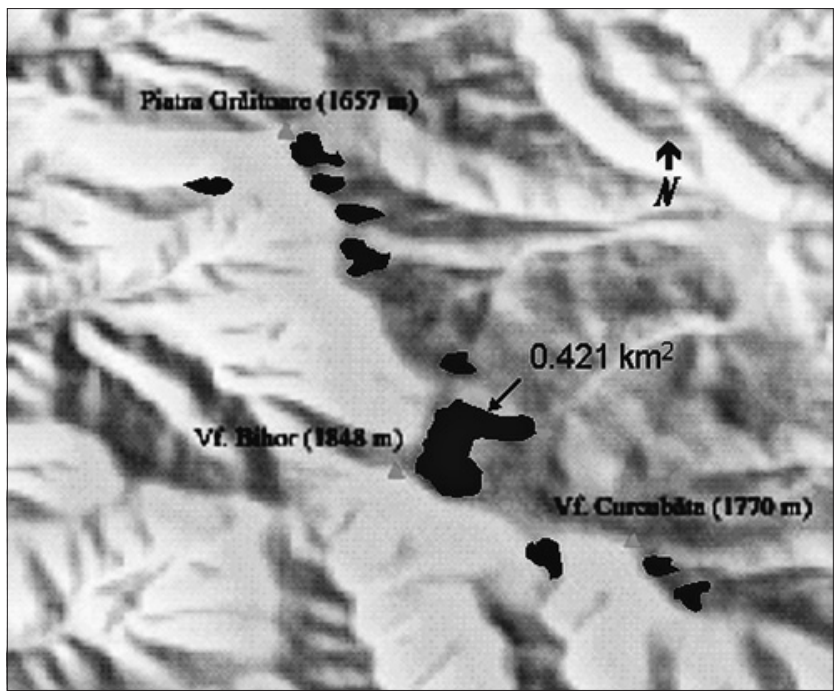

Figure 8 The reconstructed Pleistocene glaciers on the 3 DEM model of the Bihor Mountains
Peak opens into a glacial valley, covered with erratic blocks, down to ca. $1340 \mathrm{~m}$. Remains of morainic arcs are found at $1675 \mathrm{~m}, 1630 \mathrm{~m}, 1550 \mathrm{~m}$ and $1340-1350 \mathrm{~m}$ and allow the reconstruction of the fluctuation of the glacier which reached a maximum surface of $0.421 \mathrm{~km}^{2}$. These evidence indicate that the Pleistocene glaciers had been much more extensive on the Eastern side of this mountain.

\section{Final remarks and conclusions}

Field data and a revision of the available literature informations allow us to establish the extension of the Pleistocene glaciers during the Last Glacial Maximum for some mountain areas of the Romanian Carpathians. Some important remarks can also be obtained from a comparative analysis of some representatively mountain units of the Southern Carpathians (the Transylvanian Alps). We found that the largest glaciated area was present not in the Făgăraş Mountains, that is the highest mountain group, but in areas with much lower altitudes, situated to the west of the Transylvanian Alps, like Retezat or Godeanu Mountains, with a total surface of the Pleistocene glaciers of $26.8 \%$ and $25.5 \%$ instead of $20.3 \%$ (Table 1). The former mountain group host also the most extensive glacier of the Romanian Carpathians, the Lăpuşnicu Mare glacier where glacier tongue came down to the lowest altitudes, below $1100 \mathrm{~m}$ a.s.l (Urdea, 1989, 2000, 2004). Just to have an idea of the present-day climatic conditions obtained in some meteorological stations of Southern Carpathians the values of Gams continentality index increase from west, $61^{\circ} 50^{\prime}$ for Tarcu meteo station 
Table 1 The surface of reconstructed glaciers of some units from SouthernCarpathains

\begin{tabular}{|c|c|c|c|c|c|c|}
\hline Mountain area & $\begin{array}{l}\text { Max. elevation } \\
\text { (m) }\end{array}$ & Longitude & $\begin{array}{l}\text { Mean altitude of the } \\
\text { end moraines }(m)\end{array}$ & Surface $\left(\mathbf{k m}^{2}\right)$ & $\begin{array}{l}\text { Surface of reconstructed } \\
\text { glaciers }\left(\mathrm{km}^{2}\right)\end{array}$ & $\%$ \\
\hline Făgăraş & 2544 & $24^{\circ} 7263$ & 1348 & 1497 & 304 & 20.3 \\
\hline Parâng & 2519 & $23^{\circ} 5400$ & 1387 & 1100 & 129. & 11.7 \\
\hline Retezat & 2509 & $22^{\circ} 8881$ & 1200 & 453 & 121.5 & 26.8 \\
\hline lezer-Păpuşa & 2462 & $24^{\circ} 9306$ & 1395 & 500 & 60.3 & 12.05 \\
\hline Godeanu & 2291 & $22^{\circ} 7149$ & 1417 & 330 & 84.3 & 25.5 \\
\hline Țarcu & 2192 & $22^{\circ} 5449$ & 1395 & 812 & 55 & 6.8 \\
\hline Leaota & 2133 & $25^{\circ} 2933$ & 1580 & 240 & 5.8 & 2.4 \\
\hline Şureanu & 2130 & $23^{\circ} 5368$ & 1555 & 1585 & 6.5 & 0.4 \\
\hline Cernei & 1928 & $22^{\circ} 5580$ & 1720 & 493 & 0.3 & 0.06 \\
\hline Muntele Mic & 1802 & $22^{\circ} 4714$ & 1535 & 105 & 1 & 0.95 \\
\hline
\end{tabular}

$\left(2180 \mathrm{~m}, 22^{\circ} 32^{\prime} \mathrm{E}, 45^{\circ} 16^{\prime} \mathrm{N}\right)$, to east, $63^{\circ} \mathrm{O} 5^{\prime}$ for Vf. Omu meteo station $\left(2505 \mathrm{~m}, 25^{\circ} 27^{\prime} \mathrm{E}, 45^{\circ} 27^{\prime} \mathrm{N}\right)$.

The large differences in the formation and evolution of the ice masses which appear, for example, between Țarcu Mountains, on one hand, and Parâng and Şureanu, on the other, are explicable through the role of the preglacial re lief. In particular, the direction of the main interfluves, that represents the ideal area for the beginning of the sculptur ing of a glacier cirque, could have played a major role. Especially important is their configuration, the wide spreading of round-shape interfluves - belonging to Borăscu sculptural complex peneplaine being common knowledge -, but also the development degree of the reception basins, with a semi- funnel aspect, favourable for snow accumulation and for the processes of glacial ice formation.

The north-south asymmetry of the relief and their position in respect to the main west and north-west winds and

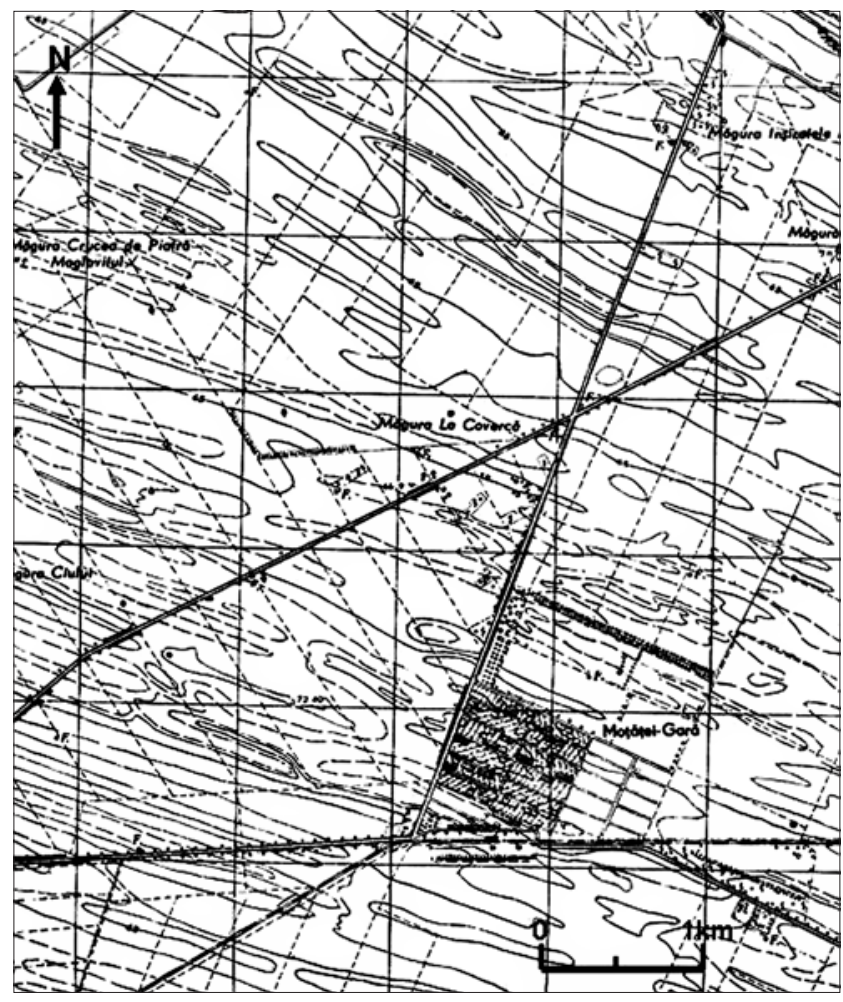

Figure 9 The topographical map of the Würmian dunes in Moțăței area (Băileştilor Plain, Romania) precipitations is another important factor. North-south climatic asymmetry is confirmed also by the distinct situation of the northern slope of the Făgăraş Mountains, with 21.8 \% $\left(111.08 \mathrm{~km}^{2}\right)$ surface affected by glaciation and the southern slope with just $19.5 \%\left(192.9 \mathrm{~km}^{2}\right)$. The northern slope, oriented towards Transsylvania, which reconfirms its favourable conditions for the development of glaciers, as consider Evans (2005). Considering that in most cases the glacial landforms are well developed and larger on the more sheltered slopes instead of those exposed to wind - we may conclude that dur ing the Pleistocene the dominant winds were those from west and north-west. - This asymetry is very well recognisable on the eastern slopes of Bihor Mountains, Muntele Mic Mountain, Sureanu Mountains, Maramureş Mountains and Leaota Mountains. All the previously mentioned locations are also dominated by rounded and gentles summit interfluves, according to the rule that the latter factor and windward slopes favour drifting snow (cf. Evans, 1977, 2005). West and north-west prevailing winds during the Pleistocene from is also confirmed by the Wurmian longitudinal and barcane dunes from Southern Oltenia (Coteț, 1957). Our recent field investigations in Băileştilor Plain confirm this orientation, well visible on the topographical map (Fig. 9).

The asymmetry of the glaciation also corresponds to the climatic asymmetry, generated mainly by the general orientation of the major relief oriented west-east, like in other Carpathains area (Klimaszewski, 1973). The most relevant situations being those of Rodnei, Călimani and Țibleş Mountains of the Eastern Carpathians and also Cindrel, Căpățânii and Parâng Mountains of the Southern Car pathians. A major role in the spreading of the Pleistocene glaciers in the Romanian Carpathians was therefore played by the interaction between the preglacial relief and of the degree of continentality which grow constantly eastwards.

On the general climatic conditions specific for the Pleistocene time the development of Quaternary glaciers in the Romanian Carpathians was controlled by: preglacial relief, the orientation of the main slopes and interfluves - with a direct influences in the appearance of the specific topoclimatic conditions-, the magnitude of climatic continentality.

Also:

- 2 high-glacial stages distinguished in the field by map ping glacial landforms and geometrical reconstruction; 
- the older moraine cannot yet be dated - pedological investigations suggest a moraine age distinctly older than $16.1 \mathrm{ka} \rightarrow$ Early Würmian or Riss;

- no field evidences for LGM advance less extensive than late glacial - likely due to increased aridity in region;

- 1 late-glacial stages is numerically dated into the Younger Dryas period.

We consider that one of the basic ideas that must be accepted is that Pleistocene glaciation in the Romanian Carpathians was more widespread than was previously considered and that it had several distinct stages in all the researched mountain units. The first radiometric dating from Pietrele Valley (Retezat Mts.) - date being also in work for Parâng and Făgăraş Mts. - indicate that in a near future, when more dating will be vailable for the most important glaciated areas of the Romanian Carpathians, the modality and time of the Pleistocene glaciation in this part of Europe will be unravelled. On the other hand, it will bee possible compare between the most glaciated area of the Romania, and, in consequence, the construction of a realistic image of the evolution of the Quaternary glaciation in this part of the Alpine-Himalayan orogenic chain.

\section{References}

Athanasiu, S. 1899. Morphologische Skizze in den Nordmoldauischen Karpathen. Buletinul Societății de Științe, București VII, 3, 232-277.

Berindei, I. 1971. Microrelieful crio-nival din Masivul Biharea. Lucrările științifice ale Institutului Pedagogic din Oradea, seria Geografie, 19-28.

Constantinescu, T. 1984. Le massif de Piatra Craiului. Génese et évolution des torrents des versants nord-ouest; glaciation pléistocene. Theoretical and Applied Karstology $1,99-106$.

Constantinescu, T. 1992. Massif de Piatra Craiului. Particularites morphogenetiques. Sous-uniés Karstikues. Travaux de l'Institut de Spéologie "Emil Racovitza" XXXI, 139-150.

Corte, A.E. 1976. Rock glaciers. Biuletyn Periglacjalny 26, 175-197.

Coteț, P. 1957. Câmpia Olteniei. Studiu geomorphologic, Edit. Științifică, București, 271 p.

Coteț, P. 1973. Geomorfologia României, Edit. Tehnică, București, $414 \mathrm{p}$.

Evans, I.S. 1977. World-wide variations in the direction and concentration of cirque and glacier aspects. Geografiska Annaler 59 A, 3-4, 151-175.

Evans, I.S. 2005. Local aspect asymmetry of mountain glaciation: A global survey of consistency of favoured directions for glacier numbers and altitudes. Geomorphology $73,1-2,166-184$.

Florea, M. 1998. Munții Făgărașului. Studiu geomorphologic, Edit. Foton, Brașov, 114 p.

Ielenicz, M., Pătru, I. 2005. Geografia fizică a României, Edit. Universitară, București, 255 p.

Inkey, B.v. 1884. Geotektonische Skizze der westlichen Hälfte des Ungarisch-Rumänischen

Grenzgebirge. Földtany Közlöny XIV, 116-121.
Inkey, B.v. 1892. Die Transsylvanischen Alpen von Rotenturmpasse bis zum Eisernen Tor., Mathematische und naturwisseschaftliche Berichte aus Ungarn IX, 20-53.

Klimaszewski, M. 1973. Conditions essential to the pleistocene glaciation of the Carpathians. Folia Geographica, Geographia Physica VII, 5-26.

Kubijovici, V. 1934. Păstoritul în Maramureș. Buletinul Societății Regale Române de Geografie LIII, 215-293.

Lehmann, P.W. 1881. Beobachtungen über Tektonik und Gletscherspuren im Fogaraschen Gebirge. Zeitschrift der Deutschen Geogischen Gesellschaft XXXIII, 109-117.

Lehmann, P.W. 1885. Die Südkarpaten zwischen Retjezat und Königstein. Zeitschrift der Geseellschaft Für Erdkunde Berlin XX, 325-336, 346-364.

Mac, I. , Covaci, I., Moldovan, C. 1990. Glaciațiune și morfologire galciară în munții mijlocii din România. Studia Universitatis "Babeș-Bolyai”, Geographia XXXV, 2, 3-11.

Martonne, Emm. de. 1907. Recherches sur l'évolution morphologique des Alpes de Transylvanie (Karpates méridionales). Revue de géographie annuelle I, (1906-1907), $286 \mathrm{pp}$.

Martonne, Emm. de. 1922. Le Massif du Bihor. In: Lucrările Institutului de Geografie al Universității din Cluj I, 47-114.

Micalevich-Velcea, V. 1961. Masivul Bucegi. Studiu geomorphologic, Edit. Academiei, București, 151 p.

Morariu, I. 1942. Vegetația muntelui Țibleș. Buletinul Societății Regale Române de Geografie LXI, 143-180.

Mrazec, L. 1898. Sur l'existence d'anciens glaciers sur le versant Sud des Karpathes méridionales. Buletinul Societății de Științe, București VIII, 2, 466-468.

Nedelcu, E. 1962. Relieful glaciar din bazinul Râul Doamnei (Munții Făgărașului). Comunicările Academiei Republicii Populare Române XII, 5, 597-603.

Niculescu, Gh. 1958. Urme glaciare și periglaciare la izvoarele văii Buta. Probleme de geografie V, 395-397.

Niculescu, Gh. 1969. Relieful glaciar din Munții Șureanu și Cindrel. Studii și cercetări de geologie, geofizică, geografie, Geografie XVI, 17-28.

Niculescu, Gh. 1971. Munții Țarcu. Caracterizare geomorfologică. Lucrările Științifice Insitutul Pedagogic Oradea, Geografie, 45-54.

Niculescu, Gh., Nedelcu, E., Iancu, S. 1983. Glaciația și relieful glaciar. In: Geografia României I-Geografia fizică, Edit. Academiei, București, 136-141.

Østrem, G. 1964. Ice-cored moraines in Scandinavia. Geografiska Annaler 46, 282-337.

Pécsi, M. 1996. Geomorphological Regions of Hungary, Geographical Research Institute, Budapest, $121 \mathrm{p}$.

Pop, Gr. 200o. Carpații și Subcarpații României, Edit. Presa Universitară Clujeană, Cluj-Napoca, 264 p.

Popescu, N. 1990. Țara Făgărașului. Studiu geomorphologic, Edit. Academiei, București, 18o p.

Posea, Gr. 1962. Țara Lăpușului. Studiu de geomorfologie, Edit. Științifică, București, 281 p.

Posea, Gr. 2002. Geomorfologia României, Edit. Fundației "România de Mâine", București, 444 p.

Posea, Gr. 2003. Geografia fizică a României, Edit. Fundației "România de Mâine", București, 264 p.

Posea, Gr., Popescu, N., Ielenicz, M. 1974. Relieful României, Edit. Științifică, București, 483 p. 
Primics, G. 1884. Die geologischen Verhältnisse der Fogarascher Alpen und des benacbarten

Rumänischen Gebirges. Mitteilungen a.d. Jahrbericht $d . k$. Ungarisch Geologische Anstalt IV, 283-315.

Puchleitner, S. 1902. Die Eiszeit Gletscherspuren in den Südkarpathen. Mitteilungen der k.k. Geographischen Gesellschaft LII, Wien, 124-139.

Reuther, A. 2005. Surface exposure dating of glacial deposits from the last glacial cycles. Evidence from the Eastern Alps, the Bavarian Forest, the Southern Carpathians and the Altai Mountains, University of Regensburg, Doctoral thesis, $246 \mathrm{p}$.

Reuther, A., Geiger, C., Urdea, P., Heine, K. 2004. Determining the glacial equilibrium line altitude (ELA) for the Northern Retezat Mts. Southern Carpathians and resulting paleoclimatic implica-tions for the last glacial cycle. Analele Universității de Vest din Timişoara, GEOGRAFIE XIV, 11-34.

Reuther, A.,Urdea, P., Geiger, C., Ivy-Ochs, S., Niller, H.P., Kubik, p., Heine, K. 2007. Late Pleistocene glacial chronology of the Pietrele Valley, Retezat Mountains, Southern Carpathians, Constrained by ${ }^{10} \mathrm{Be}$ exposure ages and pedological investigations, Quaternary International 164-165, 151-159.

Sawicki, L. 1909. A Biharhegység eljegesedésének kérdéséhez. Földrajzi Közlemenyek XXXVII, 10, 316-325.

Sawicki, L. 1911. Die glazialen Züge der Rodnaer Alpen und Marmaroscher Karpaten. Mitteilungen d.k.k. Geographische Gesellschaft in Wien LIV, IX-X, 510-571.

Sawicki, L. 1912. Les études glaciaire dans les Karpates. Apercu historique et critique. Annales de Géographie XXI, Paris, 230-250.

Szadeczky, J. 1906. Glecsernyomok a Biharhegységben. Földrajzi Közlemenyek XXXIV, 8, 299-304.

Sîrcu, I. 1978. Munții Rodnei. Studiu morfogeografic, Edit. Academiei, București, 112 p.

Tantău, I., Reille, M., de Beaulieu, J-L., Farcas, S. 2005. Late Holocene vegetation history in the southern part of
Transylvania (Romania): pollen analysis of two sequence from Avrig. Journal of Quaternary Science 21,1, 49-61.

Tietze, K. 1878. Über das Vorkommnis der Eiszeitspuren in den Ostkarpathen. Verhandlungen der geologische Reichsanstalt, Wien, 142-146.

Urdea, P. 1989. Munții Retezat. Studiu geomorfologic, Teză de doctorat, Universitatea "Al.I. Cuza" Iași, 186 p.

Urdea, P. 1992. Considerații asupra dinamicii postglaciare a etajelor morfoclimatice din Munții Retezat. Analele Universității Timişoara, Seria Geografie I, 25-31.

Urdea, P. 1993. Considerații asupra manifestării glaciației cuaternare în Munții Retezat. Studii și cercetări de geografie XL, 65-72.

Urdea, P. 1997. Aspects concerning postglacial and presentday landforms evolution in Southern Carpathians. Acta Facultatis Rerum Naturalium Universitatis Comenianae, Geographica 40, 107-117.

Urdea, P., 200o. Munții Retezat. Studiu geomorphologic, Edit. Academiei Române, București, 272 p.

Urdea, P. 2004. The Pleistocene glaciation of the Romanian Carpathians. In: Ehlers, J, Gibbard, P.L. (Ed.). Quaternary Glaciations - Extent and Chronology, Part 1 Europe, Elsevier B.V., 301-308.

Urdea, P., Cheslerean, C. 1998. Munții Tulișa. Considerații geomorfologice (II). Analele Universității de Vest din Timișoara, Seria Geografie VIII, 25-37.

Urdea, P., Drăguț, L. 2002-2003. Noi date supra reliefului glaciar și periglaciardin Munții Șureanu. Studii șicercetări de geografie XLIX, 190-206.

Velcea, V. 1973. De l'éxistence d'une glaciation de type carpatique. Revue de géographie alpine LXI, 2, 223-230.

Velcea, V. 2001. Geografia fizică a României, Edit. Universității "Lucian Blaga", Sibiu, 355 p.

Wachner, H. 1929. Die Eiszeitgletscher des Bucegi in den Südkarpaten (Rumänien). Zeitschrift für Gletscherkunde XVIII, 4-5, 67-76.

Wachner, H. 1930. Urme de ghețari în munții Bucegi. Anuarul Institutului Geologic al României (1929) XIV, 67-76. 